\title{
EL COMPONENTE RETÓRICO Y EL COMPONENTE SIMBÓLICO EN LA PUBLICIDAD. ANÁLISIS DE LOS ANUNCIOS DE ENERGÍA EÓLICA DE IBERDROLA ${ }^{1}$
}

\author{
Alfonso Martín Jiménez \\ Universidad de Valladolid
}

\begin{abstract}
RESUMEN: El propósito de este artículo consiste en compaginar dos de las metodologias analiticas que pueden explicar las estrategias persuasivas empleadas en la publicidad: la de la Retórica y la de la Poética del imaginario, de cara a analizar una serie de anuncios publicitarios de la empresa Iberdrola sobre energía eólica. Se pretende analizar no solo el componente argumentativo de los anuncios, sino también su componente simbólico-imaginario, valorando en qué medida la presencia y la manipulación de los símbolos colabora a la persuasión.
\end{abstract}

PALABRAS CLAVE: Retórica, Poética del imaginario, persuasión, símbolos, publicidad, energía eólica.

\section{THE RHETORICAL AND SYMBOLIC COMPONENT IN ADVERTISING. ANALYSIS OF THE IBERDROLA WIND ENERGY ADS}

\begin{abstract}
This article proposes to combine two of the analytical methodologies that help to explain the persuasive strategies employed in advertising: Rhetoric and Poetics of the imagination, in order to analyze a series of advertisements of the wind energy company, Iberdrola. It is intended not only to analyze the argumentative component of the ads, but also their symbolic-imaginary component, evaluating how the presence and the manipulation of symbols help persuasion.
\end{abstract}

KEYWORDS: Rhetoric, Poetics of the imagination, persuasion, symbols, advertising, wind farms.

1. Este artículo es resultado de una investigación realizada en el marco del proyecto de investigación "Comunicación en la Empresa y en las Instituciones: mecanismos discursivos de gestión del conocimiento y persuasión social", financiado por el Ministerio de Ciencia e Innovación español, periodo 1-1-2011 al 31-12-2013. Referencia FFI2010-18514 (subprograma FILO). 
En este artículo se pretende crear un método de análisis mixto de las estrategias de persuasión publicitarias, basado en la valoración del componente retórico y del componente simbólico de los anuncios publicitarios. Los anuncios de televisión constituyen discursos de tipo persuasivo que pueden ser analizados con los recursos descritos por la Retórica tradicional (Perelman 1988; Albaladejo 1989; Lausberg 1990, 1993; Mortara 1991; Pujante 2003; Hernández y García 2004), por la moderna Teoría de la Argumentación (Perelman y Olbrechts-Tyteca 1994) o por el Análisis Crítico del Discurso (Pujante y Morales López 1996-97, 2003, 2008; van Dijk 1997, 1999, 2001; Fairclough 2001; Wodak y Meyer 2001: p. 30 y 69; Blommaert 2005; Morales López 2004). Pero, además, su eficacia persuasiva está ligada a los efectos que se consiguen con el uso de los símbolos, por lo que el análisis de la simbología imaginaria desplegada en los mismos puede ayudar a entender mejor su naturaleza. Para ello, podemos valernos de las aportaciones de la denominada Poética del imaginario (Bachelard 1942, 1948a, 1948b, 1957, 1958, 1961, 1966; Durand 1960, 1961, 1979, 1994; 1996), o Poética de la imaginación, la cual ha sido desarrollada fundamentalmente para el análisis de los discursos literarios (Burgos 1982; García Berrio 1985, 1994; Rubio 1991; Martín 1993), pero que también resulta de utilidad, a mi modo de ver, para comprender el componente simbólico de la publicidad. No hay que olvidar que, ya en la Antigüedad grecolatina, se estableció un claro nexo entre los discursos poético (o literario) y retórico, por valerse ambos de un tipo de lenguaje común, o sermo ornatus (discurso adornado), basado en el uso del lenguaje estándar con el añadido de los recursos estilísticos y de las figuras retóricas. En consecuencia, si el discurso literario y el discurso retórico-persuasivo tienen elementos en común, también pueden tenerlos los métodos desarrollados para analizarlos.

Mi intención consiste, pues, en desarrollar una nueva metodología analítica que aúne las aportaciones de la Retórica y de la Poética del imaginario, así como aplicar y ejemplificar el uso de dicha metodología con el análisis de un tipo concreto de anuncios publicitarios: los llevados a cabo en los últimos años por la empresa eléctrica Iberdrola sobre la energía eólica.

La metodología suministrada por la Retórica y por la nueva teoría de la argumentación ha sido puesta en práctica de manera provechosa en el análisis de anuncios publicitarios de los más diversos productos, por lo que no voy a extenderme en su descripción. Baste considerar que los anuncios publicitarios constituyen un tipo de discurso claramente retórico-persuasivo, destinado a lograr que los consumidores hagan algo en el futuro (básicamente, comprar determinados productos o 
valorar positivamente determinadas marcas comerciales en detrimento de otras de la competencia).

Como es bien sabido, Aristóteles distinguió en su Retórica (1985) tres tipos o géneros de discursos: el discurso judicial, que se pronunciaba ante los tribunales y trataba sobre cosas pasadas, de manera que se juzgaba el grado de culpabilidad del acusado en el delito que se le imputaba; el discurso político o deliberativo, que se pronunciaba ante las asambleas de tipo político y versaba sobre cosas futuras, incitando a los destinatarios a hacer en el futuro (o a dejar de hacer) lo que aconsejaba el orador, y el discurso epidíctico o demostrativo, cuya finalidad era alabar (laudatio) o censurar (vituperatio) el comportamiento en el pasado de determinada persona o institución. Estos tres géneros retóricos, a juicio de Áron Kibédi Varga, tienen una validez transhistórica y transcultural, y pueden considerarse el modelo básico de cualquier tipo de discurso retórico imaginable en cualquier momento histórico y en cualquier circunstancia cultural:

Curieusement, la trichotomie séculaire des genres oratoires n'a pas changé depuis leur formulation première, et ils se retrouvent dans les civilisations non occidentales: l'écrit aussi bien que l'oral, le médial aussi bien que l'écrit relèvent toujours de l'un des trois genres, épidictique, judiciaire et délibératif. L'orateur, l'écrivain et le présentateur à la télévision font l'éloge d'un grand homme ou d'une grande cause -ils misent sur le consensus épidictique-, ils nous apportent des arguments pour juger une affaire -genre judiciaire- ou ils cherchent à nous convaincre de la vérité à laquelle ils adhèrent, admettant ainsi le dialogue délibératif avec le récepteur. Toutes les tentatives d'ajouter d'autres genres à ces trois là ont échoué... (Kibédi Varga 2000: 22-23)

En este sentido, los anuncios publicitarios, sin constituir tipos de discursos políticos o deliberativos en el sentido estrictamente aristotélico, se relacionan fundamentalmente con ellos, ya que ambos están destinados a mediatizar el comportamiento de los destinatarios en el futuro. No obstante, los discursos retóricos pueden adscribirse a más de un género oratorio, por lo que Tomás Albaladejo propone

introducir el concepto de componente genérico, distinto del género retórico pero vinculado a él [...]. De este modo, habría un componente genérico judicial, un componente genérico deliberativo y un componente genérico demostrativo o epidíctico. Por lo general, los discursos retóricos tienen más de un componente genérico como constituyente textual, son discursos que contienen varios componentes genéricos; sin embargo, puede detectarse en los discursos que uno de 
estos componentes genéricos que actúan como constituyentes textuales es el componente central o dominante, el cual determina la adscripción genérica del discurso de que se trate. (Albaladejo 1999, p. 59)

Así, los anuncios publicitarios suelen tener un componente central o dominante de tipo deliberativo, pero pueden incorporar además otro componente demostrativo o epidíctico, por cuanto suponen un elogio del producto que se anuncia o un vituperio de los productos de otras compañías. E incluso podrían incluir un componente judicial, si se censurara, por ejemplo, la falta de honestidad de las empresas de la competencia.

Por otra parte, el tipo particular de discurso retórico que constituyen los anuncios publicitarios tiene otras características que le distinguen de los discursos retóricos clásicos establecidos por Aristóteles, siendo la principal diferencia el hecho de que los anuncios estén basados en imágenes audiovisuales que llegan directamente al espectador, sin necesidad de que aparezca un orador encargado de pronunciar el discurso. Existen, no obstante, determinados anuncios que se asemejan más a los discursos retóricos tradicionales, ya que en ellos aparece una persona que pronuncia ante los destinatarios un discurso persuasivo; pero muchos de los anuncios publicitarios eliden la presencia directa del orador, que es sustituida por una voz en off, o por una pluralidad de personas que emiten parlamentos más o menos uniformes y con la misma finalidad persuasiva, de manera que el mensaje parece reforzarse por provenir de varios emisarios que lo sustentan. Mientras que los rétores clásicos se esforzaban por medio de sus palabras en poner ante los ojos de los destinatarios determinadas imágenes a través de técnicas descriptivas, como la evidentia, los anuncios publicitarios muestran directamente esas imágenes; y si los rétores clásicos describían lingüísticamente el comportamiento de las personas de las que hablaban, los anuncios pueden mostrar directamente los comportamientos humanos, sugiriendo que producen resultados más o menos satisfactorios en conformidad con el tipo de productos que se compren o utilicen. Por lo demás, los anuncios publicitarios no solo pueden servirse de la imagen, sino de otros códigos semióticos, como la música o las canciones, que no eran empleados en los discursos tradicionales. Frente a los discursos retóricos clásicos, constituidos básicamente por el discurso lingüístico y paralingüístico del orador, por su atavío, por sus gestos y sus movimientos, el anuncio publicitario puede prescindir de la presencia directa del orador y de su discurso, y sustituirlo por un mensaje transmitido a través de imágenes o sonidos, llegando en ocasiones a limitar al máximo el componente lingüístico.

Y es precisamente la importancia que adquiere la imagen en los anuncios publicitarios lo que determina que la metodología suministrada por la Poética de la imagi- 
nación pueda resultar de utilidad para explicar su eficacia persuasiva. En efecto, dicha corriente analítica se preocupa por determinar la naturaleza de las imágenes y de los símbolos que comportan, valorando su carácter a la vez universal y particular. En el caso de los textos literarios, su eficacia comunicativa depende, según esta corriente, de que lleguen a transmitir de manera novedosa, llamativa $u$ original determinados símbolos de naturaleza universal, de manera que su universalidad asegura la identificación entre el autor y los receptores, y su originalidad el que los destinatarios se sientan atraídos por algo que les concierne. Considero que estos principios son perfectamente aplicables a los anuncios publicitarios, puesto que en ellos también se pueden presentar de manera original una serie de símbolos de naturaleza universal, con la pretensión de que los destinatarios se sientan a la vez atraídos e identificados con ellos. Y el hecho de que los espectadores valoren la originalidad de los anuncios y perciban de manera intuitiva que transmiten una serie de símbolos universales que sienten como propios puede determinar su eficacia persuasiva.

Según la teoría retórica tradicional, el rétor debía construir su discurso siguiendo las pautas establecidas al efecto, poniendo en juego los recursos suministrados por las operaciones retóricas de la inventio (o hallazgo de las ideas o argumentos), la dispositio (encaminada a disponer las partes del discurso de la manera más adecuada para la persuasión) y la elocutio (que propiciaba el adorno del discurso por medio de figuras retóricas y del uso adecuado de los procedimientos estilísticos). El discurso bien elaborado, dispuesto y adornado debía ser después memorizado (a cuyo efecto se indicaban una serie de consejos en la operación retórica de la memoria), permitiendo al orador, claro está, la posibilidad de improvisar cuando fuera necesario o conveniente, y debía ser pronunciado de manera oportuna con el refuerzo de la mímica y la gesticulación (siendo la operación retórica de la actio o pronuntiatio la encargada de suministrar normas y preceptos al respecto). Así, si un orador pronunciaba de manera eficaz un discurso adecuadamente compuesto, estructurado y adornado, y el oyente no era consciente de su carácter artificioso, podía creer que el orador estaba improvisando y sentir que él no sería capaz de hablar así, y el hecho de reconocer la superioridad lingüística del orador le predisponía a dejarse convencer por sus palabras. E incluso en los casos en los que los destinatarios conocieran perfectamente los mecanismos persuasivos de la retórica, podrían reconocer la maestría del orador al emplearlos, viéndose por ello impelidos a admitir su habilidad, con la consecuente tendencia a dejarse influir por su mensaje.

Pues bien, creo que en los discursos retóricos en general, y en los anuncios publicitarios en particular, se puede producir un efecto persuasivo complementario derivado de la adecuada transmisión de una serie de imágenes y símbolos con los que 
los receptores puedan sentirse identificados. De igual manera que la apropiada construcción, memorización y pronunciación del discurso retórico puede causar en el receptor un sentimiento de admiración que le hace proclive a dejarse persuadir por el orador, la transmisión de manera atractiva y original de una serie de símbolos universales puede influir en el receptor, al reconocer el carácter a la vez singular y universal de los símbolos que se le presentan: si el anuncio está bien construido desde un punto de vista simbólico-imaginario, el receptor puede admitir que se le habla de algo que le concierne, y que se hace además de una manera original, lo que le predispone también a aceptar cierta habilidad en el emisor (o emisores) del anuncio, con la consiguiente tendencia a dejarse influir por su mensaje. El mecanismo es similar al que se produce en la comunicación literaria: si el lector admite el mérito o el ingenio artístico del autor, se vuelve proclive a valorar su obra y a dejarse influir por su mensaje.

Naturalmente, la dificultad estriba en definir en qué consiste un componente simbólico-imaginario bien construido. Mientras que los antiguos rétores no ponían en duda la eficacia del sometimiento a las normas, considerando que cualquier autor que dominara la técnica retórica y tuviera cierto talento podía llegar a construir buenos discursos de reconocida eficacia persuasiva, la concepción contemporánea sobre la calidad de las obras de arte se caracteriza por su relativismo, de manera que se ha puesto en entredicho la propia posibilidad de juzgar de manera objetiva la valía de los objetos artísticos o literarios (Genette 2000). Y ese escepticismo puede extenderse no solo al ámbito de los discursos retóricos, sino también al de los anuncios publicitarios: aunque no se otorgue el mismo valor a la creación de estos últimos que al de las obras artísticas, puede ponerse en entredicho no solo su calidad o eficacia persuasiva, sino la propia posibilidad de establecer criterios objetivos que pudieran definirlas.

Teniendo en cuenta esas dificultades, no me propongo establecer un sistema analítico capaz de determinar de forma objetiva la validez o la eficacia persuasiva de los anuncios publicitarios, sino tan solo contemplar la existencia en ellos de un componente simbólico que podría ayudar a explicar su naturaleza. Y, para ello, sería conveniente, en primer lugar, describir someramente los postulados de la clasificación de los símbolos antropológicos establecida por Gilbert Durand, como paso previo a valorar la pertinencia de la aplicación de sus presupuestos al análisis de los anuncios.

En su obra Estructuras antropológicas de lo imaginario (1960), Gilbert Durand se propuso explicar la imaginación humana y sus productos, como los mitos, los ritos de iniciación, las religiones, el pensamiento filosófico o las creaciones artísticas. A juicio de Durand, existe una naturaleza psíquica común a todos los hombres, resultante de nuestra herencia genética, pero esa naturaleza psíquica solo se 
manifiesta y se desarrolla en el ámbito de una cultura determinada. De ahí que existan unos arquetipos universales, determinados por la naturaleza psicobiológica del hombre, y que esos arquetipos den lugar a símbolos aparentemente muy diferentes en las distintas culturas y sociedades ${ }^{2}$.

Para establecer su clasificación, Durand parte del psiquismo humano y de los reflejos dominantes en los niños recién nacidos, estudiados por el reflexólogo Vladimir M. Betcherev: el reflejo postural o de posición, que inhibe los demás reflejos cuando se alza verticalmente el cuerpo del niño; el reflejo de nutrición o de digestión, que se produce cuando el niño se concentra en succionar la leche del pecho materno, y el reflejo sexual, que se relaciona con el ritmo. Cada uno de estos tres reflejos dominantes, comunes a todos los hombres, da lugar a una serie de arquetipos y símbolos. Algunos de los símbolos, además, tienen significados equivalentes, por lo que son susceptibles de ser agrupados en constelaciones, que Durand llama regímenes. El reflejo postural da lugar a una serie de símbolos relacionados con la luminosidad que constituyen el Régimen Diurno, mientras que el Régimen Nocturno, asociado al interior del cuerpo y a la intimidad, consta de dos dominantes: la digestiva, determinada por el reflejo digestivo, y la sexual, originada por el reflejo sexual. Reproducimos de manera sintética la clasificación de Gilbert Durand (1960: 71-363):

2. El carácter universal del comportamiento humano, así como la capacidad de comprender a los demás y de comunicarnos con ellos, atribuible en última instancia a la anatomía común de nuestro cerebro, ha sido puesto de manifiesto por la moderna neurociencia. A este respecto, Marc Jeannerod, Director de l'Institut des Sciences Cognitives de France, escribía lo siguiente: "Imaginons ce que serait la vie d'un groupe dont les individus posséderaient des cerveaux construits de manière différente. Il serait impossible à chacun de ses membres de prévoir et de comprendre les réactions des autres, et donc impossible de communiquer et d'échanger de l'information [...]. L'invariance du cerveau humain, fondée sur une anatomie commune, est la condition de notre vie d'espèce" (Jeannerod 2002, 19). En el mismo sentido, Joseph Ledoux, profesor del Centro de Neurología de la Universidad de Nueva York, ha mostrado el carácter universal de nuestras emociones (Ledoux 1999), y el reciente descubrimiento de las denominadas "neuronas espejo" evidencia que estamos preparados para comprender las intenciones y los sentimientos ajenos, debido a que dichas neuronas simulan en nuestro cerebro los movimientos o gestos que vemos hacer a los demás, lo que nos permite comprender inconscientemente lo que nosotros mismos querríamos hacer o sentiríamos al realizar esos gestos o movimientos (Rizzolatti y Sinigaglia 2006: 13; Iacoboni 2010). Por ello, si existen mecanismos universales garantes de la vida de especie que nos permiten comprender las emociones y las intenciones de los demás, nada tiene de extraño que compartamos también, como sostenía Durand, un sistema universal de arquetipos y símbolos, derivado de la anatomía común de nuestro cerebro, el cual puede adoptar diferentes manifestaciones en los distintos momentos históricos y en el seno de cada cultura. 


\section{RÉGIMEN DIURNO}

\section{A) LOS ROSTROS DEL TIEMPO:}

- Símbolos teriomorfos: caballo, toro, fauces, lobo, perro, león, tigre, jaguar, ogro, dragón...

- Símbolos nictomorfos: tinieblas, negrura, ciego, agua corriente, dragón, lágrimas, cabellera, sangre menstrual, luna, mujer fatal, araña, pulpo, lazo...

- Símbolos catamorfos: caída, carne (digestiva, sexual)...

B) EL CETRO Y LA ESPADA:

- Símbolos ascensionales: montaña sagrada, piedras erguidas, ala, ángel, flecha, gigantización, cetro, soberanía (militar, jurídica y religiosa), cielo, paternidad, espada, cráneo, cola, cornamenta, caza, prácticas cinegéticas y guerreras...

- Símbolos espectaculares: luz, sol naciente, oriente, corona solar, tonsura, ojo, palabra-mantra, videncia...

- Símbolos diairéticos: héroe armado, armas cortantes, herramientas aratorias, armas percutientes, ritos de purificación (escisión, circuncisión...), agua limpia, fuego, aire...

\section{RÉGIMEN NOCTURNO}

\section{A) DOMINANTE DIGESTIVA (LA COPA):}

- Símbolos de la inversión: descenso, deglución, vaguedad e inefabilidad, reduplicación y encajonamientos, gulliverización, pez, noche tranquila, colores, melodía, feminidad positiva, maternidad, mar, tierra...

- Símbolos de la intimidad: continentes y contenidos, ritos de enterramiento, sueño, cuna y sepulcro, momia, caverna, casa, bosque sagrado, centro, morada sobre el agua (arca, barca...), coche, alimento, leche materna, miel, vino, oro, excremento...

B) DOMINANTE SEXUAL (EL DENARIO Y LA RUEDA):

- Símbolos cíclicos: año, calendario, luna cíclica, divinidades plurales (díadas o tríadas), andrógino, eterno retorno, agricultura, tumba vegetal, hijo, doble paternidad, ceremonias iniciáticas, sacrificios, prácticas orgiásticas, bestiario cíclico (caracol, oso, insectos, crustáceos, batracios, reptiles -serpiente-), tejido e hilado, círculo, swastika...

- Símbolos del progreso: utensilios de progreso (torno, industria textil...), cruz, encendedor, sexualidad, danzas y cantos rítmicos, árbol...

3. En un primer momento (concretamente en su obra Las estructuras antropológicas de lo imaginario, de 1960), Durand estableció esta clasificación de carácter a la vez binario y ternario, formada por el Régimen Diurno y el Régimen Nocturno, de manera que éste se subdividía en las dominantes digestiva y sexual. Posteriormente (Durand, 1974: 249-289), se referiría simplemente a tres estructuras (esquizomorfas, intimistas y diseminatorias) o a tres regímenes de la imaginación, que podríamos denominar Régimen Diurno, Régimen Nocturno propiamente dicho (formado por la dominante digestiva) y Régimen Cíclico-Sexual (formado por la dominante sexual). Antonio García Berrio, por su parte, se refiere a esas tres estructuras con las denominaciones de Régimen Diurno, Régimen Nocturno y Régimen Copulativo (García Berrio 1994: 394). 
Los símbolos no solo son el resultado de los reflejos dominantes, sino que constituyen formas de dar respuesta a la angustia que nos produce el paso del tiempo y la consciencia de la muerte. El Régimen Diurno incluye en primer lugar una serie de símbolos que se relacionan entre sí, y que son agrupados bajo el epígrafe denominado "Los rostros del tiempo". Se trata de una serie de símbolos que sustituyen al propio tiempo, y que tienen un valor negativo, pero, aun siendo temibles, no lo son tanto como el propio tiempo, lo que constituye una primera forma de consuelo imaginario: el tiempo es sustituido por una serie de símbolos teriormorfos relacionados con animales veloces o que podrían devorarnos y causarnos la muerte. Asimismo, el tiempo es suplantado por una serie de símbolos nictomorfos, relacionados con las tinieblas y con la negrura en general. En este grupo se incluye el agua corriente, heraclitea, cuyo movimiento perpetuo la convierte en fácil símbolo del paso del tiempo, o la luna, cuya forma cambiante se asocia directamente al tiempo. Además, como los ciclos lunares tienen una duración parecida a los ciclos menstruales, se establecerá una relación entre la luna y la mujer, dando lugar al símbolo de la mujer fatal. Por último, se incluyen en esta constelación una serie de símbolos catamorfos relacionados fundamentalmente con la caída y el aplastamiento, así como con los pecados de la carne.

A estos símbolos negativos de "Los rostros del tiempo" se oponen otros símbolos positivos, incluidos en el epígrafe de "El cetro y la espada" (Durand se sirve para denominar a este apartado de dos cartas del Tarot), que simboliza el poder y las armas. A cada uno de los tres tipos de símbolos de "Los rostros del tiempo" se enfrentará ahora un tipo de símbolos de "El cetro y la espada". Contra los símbolos catamorfos de la caída se alzan los símbolos ascensionales, que estiman la elevación, el vuelo y la gigantización; frente a los símbolos nictomorfos de la oscuridad se afianzan los símbolos espectaculares, que valoran positivamente la luz, el sol naciente y la claridad. Y a los símbolos teriomorfos de los animales potencialmente peligrosos se oponen los símbolos diairéticos, que incluyen los héroes armados capaces de matar a esos animales y la simbología de la purificación (agua limpia, fuego y aire). De esta forma, la imaginación sustituye el tiempo por un animal teriomorfo, como un ogro o un dragón, e inventa después un héroe armado capaz de matar al monstruo, con lo que se consigue vencer simbólicamente al tiempo.

El Régimen Nocturno, en su dominante digestiva (que Durand simboliza con la carta del Tarot de "La copa") invierte el valor negativo de los símbolos de "Los rostros del tiempo", convirtiéndolos en positivos, en un proceso al que Durand se refiere como "eufemización". Por ello, la dominante digestiva (el Régimen Nocturno propiamente dicho) incluye una serie de símbolos de la inversión: la terrible 
caída catamorfa se convierte en un plácido descenso, las fauces teriomorfas se convierten en una simple deglución, de manera que el ser tragado sale vivo del vientre del animal, y la noche nictomorfa, terrible y oscura, se transforma en una noche agradable en la que tienen lugar las experiencias místicas o los encuentros amorosos con mujeres que son ahora valoradas positivamente; asimismo, los héroes diurnos, caracterizados por su tendencia a la gigantización, son sustituidos por seres "gulliverizados", es decir, pequeñitos, los cuales vencen al ogro o al monstruo teriomorfo no por su fuerza, sino por su astucia. Los símbolos de la intimidad, por su parte, se relacionan con la alimentación, los recipientes alimenticios y con la protección materna, y permiten crear espacios protegidos en los que sentirse a salvo del paso del tiempo.

Y la dominante sexual, o Régimen Copulativo (que Durand simboliza con las cartas del Tarot de "El denario" - antiguo calendario de diez meses- y "La rueda"), convierte la línea del tiempo en un círculo o rueda, de manera que nada acaba, sino que todo vuelve a nacer. Por ello, los símbolos cíclicos incluyen el año, el calendario, los ciclos de la luna, la muerte y la resurrección o el hijo. Así, aunque un año se acabe, celebramos que vendrá otro después, y aunque nosotros muramos, nos consuela saber que nuestros hijos continuarán nuestra estirpe en la tierra. Los símbolos del progreso, por su parte, se asocian a los utensilios rítmicos que hacen progresar al hombre y al carácter rítmico de la sexualidad, y tienden a ignorar lo que el paso del tiempo trae de negativo, destacando los aspectos positivos del paso del tiempo (como la adquisición de experiencia, o la acumulación de riquezas).

Para una explicación más pormenorizada de la clasificación de Durand, remitimos a su mencionada obra (1960), así como a sus posteriores trabajos (1961, $1979,1994,1996)^{4}$. Y aunque a dicha clasificación sin duda se le podrían poner

4. Existe la posibilidad, no contemplada expresamente en la clasificación de Durand, de subvertir el valor originariamente atribuido a los símbolos. Así, es posible subvertir el carácter positivo que tienen algunos símbolos con una finalidad satírica o humorística; por ejemplo, el carácter viril y aguerrido de los héroes diairéticos se ve claramente subvertido en la figura de don Quijote, cuyas características físicas son totalmente opuestas a las que se esperarían de un auténtico caballero andante. De igual forma, los valores originarios de cualquiera de los símbolos de la clasificación de Durand pueden ser subvertidos. La idea de la subversión de los símbolos de la clasificación de Durand fue propuesta por Francisco Zea Álvarez (2003). Se eligió el término subversión, y no el de inversión, ya que Durand empleó este último término para definir la naturaleza de una parte de los símbolos nocturnos, que invertían los valores de los símbolos diurnos. Luis Carlos Salazar Quintana (2009) desarrolló la idea en su Tesis Doctoral, analizando la subversión de los símbolos en la propia figura de don Quijote y en otros aspectos de la obra cervantina. 
pegas, como la ausencia de algunos símbolos importantes, y a pesar de que podría ser mejorable, su misma elaboración deja claro, al menos, que es posible establecer una sistematización de los productos de la imaginación, basada en el hecho de que algunos símbolos se asocian con otros formando grupos susceptibles de ser encuadrados en regímenes.

Teniendo en cuenta la clasificación de Durand, pasamos a analizar los recursos retóricos y la presencia complementaria de símbolos en algunos anuncios publicitarios sobre energía eólica de la empresa eléctrica Iberdrola, emitidos en las distintas televisiones españolas entre los años 2007 y 2012.

Nos interesa analizar, especialmente, aquellos anuncios en los que aparecen molinos de energía eólica, y la imagen que se transmite de los mismos. Y ello es debido a que la instalación de ese tipo de molinos en las distintas provincias de nuestra geografía no ha estado exenta de controversia. Por un lado, parece claramente deseable la sustitución de las energías tradicionales por tipos de energía "verde" o renovable, como la energía eólica o la solar. El moderno ecologismo ha reclamado con insistencia la implantación de las energías renovables y el abandono de otro tipo de energías altamente contaminantes, como la derivada de la combustión de hidrocarburos, que se considera responsable del efecto invernadero y del calentamiento del planeta, o la energía atómica, cuyas instalaciones implican un cierto grado de riesgo de accidente nuclear (puesto recientemente de manifiesto en el caso de la central nuclear de Fukhusima) y cuyos residuos, con efectos radiactivos de gran duración, comportan un problema de almacenamiento. Las energías renovables, en cambio, no contaminan (o lo hacen en una medida mucho menor que las energías tradicionales), por lo que parecen claramente preferibles, siendo su principal inconveniente que, hoy por hoy, no alcancen a producir por sí solas la cantidad deseada de energía. No obstante, siempre sería preferible obtener cierta cantidad de energía de manera no contaminante, y es de esperar que, con el desarrollo de la tecnología, las energías renovables puedan llegar a sustituir a las tradicionales.

Pero si en sí mismas la energía eólica o la energía solar tienen claras ventajas, no es menos cierto que presentan un claro inconveniente, derivado de la forma indiscriminada de implantarse, como ha ocurrido en nuestro país: tanto las instalaciones de energía solar como los parques eólicos suponen en no pocas ocasiones un auténtico atentado contra el valor paisajístico de los lugares en los que se emplazan. Así, en los últimos quince años hemos podido comprobar cómo algunos de los paisajes más atractivos y estimados de nuestro país han sido literalmente invadidos por 
la presencia masiva de molinos de viento o - hasta el momento en menor medida-por las instalaciones de energía solar. En el caso de estas últimas, es evidente que podrían emplazarse en lugares que no dañaran el paisaje, como los tejados de las edificaciones, y que, si se sitúan en los campos, es debido exclusivamente al menor coste que supone su instalación. Por lo que respecta a los parques eólicos, se ubican en lugares -muchas veces elevados- en los que sople suficientemente el viento, lo que, unido al gran tamaño de los molinos, y al gran número de los mismos, determina que sean visibles desde largas distancias, con el consiguiente daño paisajístico. Así las cosas, los ecologistas o los amantes de la naturaleza defienden las energías renovables como algo imprescindible para la salvación del planeta, pero se han encontrado -de forma tal vez inesperada- con que la implantación arbitraria de parques eólicos supone una agresión paisajística a la naturaleza, cuya conservación es otra de sus premisas básicas. Y, hasta el momento, no parecen haber resuelto la contradicción derivada de que el carácter artificial de los molinos atente contra el valor natural de los espacios en que se instalan. La respuesta a esa aparente contradicción parece obvia: se debe promover la energía eólica, pero instalando los parques en parajes de escaso valor paisajístico, o concentrando al máximo los molinos en espacios determinados, en lugar de diseminarlos por distintos lugares, para minimizar todo lo posible el daño que causen al paisaje. Sin embargo, esa solución no interesa a las empresas eléctricas, que están interesadas en instalar los parques eólicos en los lugares en los que resulten más rentables, con independencia de su valor paisajístico. Por ello, las empresas eléctricas se han aprovechado de la contradicción o de la indecisión de los movimientos ecologistas, apropiándose de una de sus consignas (la promoción de la energía eólica), e ignorando claramente la otra (la conservación de los espacios naturales y del paisaje) ${ }^{5}$.

De hecho, la proliferación de parques eólicos en todo tipo de lugares, muchos de los cuales tenían un inestimable valor paisajístico antes de su instalación, incita a pensar que las administraciones han otorgado las licencias a las empresas por

5. Conviene recordar al respecto el concepto de marco, propuesto por Erving Goffman (2006) y desarrollado por la teoría lingüística cognitiva, entre otros, de George Lakoff (2007), según los cuales los discursos humanos se enmarcan en unas concepciones determinadas sobre nosotros mismos, sobre los demás y sobre el mundo en el que vivimos. Los marcos pueden ser considerados como ideologías, es decir, como creencias o marcos compartidos por grupos sociales más o menos amplios, y a menudo enfrentados por la obtención de unos recursos limitados. Los anuncios publicitarios suelen aprovecharse de marcos o ideologías ya construidas y asumidas para potenciar sus productos (Pujante, 2010), o refutarlas para abrir nuevos mercados o cambiar actitudes y opiniones. En el caso de la energía eólica, las empresas eléctricas se han aprovechado claramente de la ideología favorable a las energías renovables para obtener beneficios económicos, tratando de minimizar, como veremos, el daño que causan a los espacios naturales. 
motivos primordialmente económicos y de manera arbitraria, y sin que se haya tenido en cuenta la opinión de la población sobre los lugares óptimos de su emplazamiento. Las empresas eléctricas contemplan la instalación de parques eólicos como un simple negocio, y no han mostrado ningún interés en proteger y conservar el paisaje, el cual constituye un bien común que están arrebatando al conjunto de la sociedad. Aunque, obviamente, no es ese el mensaje que procuran transmitir a la población. Antes al contrario, su publicidad, como la de cualquier otro tipo de empresas, está destinada a ofrecer una imagen positiva de sí mismas, ocultando los aspectos negativos de su actividad, o tratando cuando menos de minimizarlos. Y en ese proceso de tergiversación no solo cumplen un importante papel los artificios persuasivos de raigambre retórica, sino también el empleo de símbolos de naturaleza imaginaria.

Los anuncios de energías renovables de Iberdrola del año 2007 estaban dirigidos fundamentalmente a captar inversores o clientes, $\mathrm{y}$, dependiendo del tipo de destinatario, presentaban el "cambio a la energía verde Iberdrola" como un negocio de futuro, del que los inversores podrían obtener beneficios, o como un acto de solidaridad de los clientes preocupados por cuidar del planeta. Como aconsejaba la técnica retórica, los anuncios presentan el lado de la realidad que le resulta conveniente al emisor del discurso, e ignoran o tratan de contrarrestar las facetas que podría ir en su contra. En los debates retóricos en los que hay dos oradores, cada uno de ellos se encarga de insistir en los aspectos que perjudican al rival, pero los anuncios publicitarios presentan muchas veces la ventaja, para quien los emite, de no contar con una voz disonante, con lo que el mensaje ofrece únicamente los aspectos que le resultan provechosos al anunciante. Así, se alaban las ventajas de la energía eólica en un doble sentido: los inversores pueden obtener de ella un provecho económico, y los clientes se verán beneficiados por el uso de una energía limpia y saludable para el planeta. Y se ignora que la implantación de parques eólicos puede suponer un perjuicio para el paisaje.

Por lo que respecta a los anuncios dirigidos a los inversores, y bajo el lema "Invierte en renovables", se realizaron anuncios sobre el agua y el aire como formas de energía limpias. En el anuncio sobre el agua ${ }^{6}$ (que solo comentaremos sucintamente por no estar relacionado con la energía eólica) una voz en off afirmaba lo siguiente: "El agua, una de las energías más limpias del planeta, puede ser tuya. Invierte en renovables". En el anuncio sobre el aire ${ }^{7}$, se presentaba a una mujer

6. Puede verse en <http://www.youtube.com/watch?v=vX7RgXZPT8E $>$ (Acceso 9 Agosto 2012).

7. En $<$ http://www.youtube.com/watch?v=PLXhw_OCfeo $>$ (Acceso 9 Agosto 2012). 
joven con su hija junto a un acantilado marino, ambas con el pelo flotando al viento; la hija lleva una bolsa de papel que se hincha con el viento que viene del mar, y, cuando la bolsa está llena, la cierra y se la lleva llena de aire a su madre. En la primera parte suena una canción en inglés, que es sustituida después por una voz en off que reproduce el mismo mensaje del anuncio sobre el agua, aunque refiriéndose ahora al viento: "El viento, una de las energías más limpias del planeta, puede ser tuya. Invierte en renovables". Y ambos anuncios acababan con un letrero verde en el que se leía "Iberdrola renovables" y el subtítulo "Próxima salida a bolsa".

Desde un punto de vista retórico, los mensajes de los dos anuncios resultan pretendidamente ambiguos: "El agua, una de las energías más limpias del planeta, puede ser tuya" / "El viento, una de las energías más limpias del planeta, puede ser tuya". Ateniéndonos a la lógica sintáctica, se dice que el agua y el viento, como sujetos de las oraciones, podrían pasar a ser propiedad del destinatario; pero la concordancia del segundo mensaje indica que lo que podría ser del receptor es la energía que producen el agua y el viento (ya que el género de viento no concuerda con el de tuya). No obstante, la construcción morfosintáctica sugiere que también el agua, y hasta algo tan inasible como el viento, podrían ser del destinatario, idea que se refuerza gráficamente con el hecho de que la niña llene la bolsa de aire, la cierre, y se la lleve a su madre. Así, no solo se estimula el deseo de obtener ganancias a través de la compra de acciones de Iberdrola, sino que se sugiere a los posibles inversores, de manera hiperbólica, que podrían llegar a ser propietarios de las fuerzas de la naturaleza. Y por lo que respecta a la construcción imaginaria, ya hemos visto que el agua y el viento (además del fuego) son los principales símbolos diairéticos ligados a la purificación, y no deja de ser significativo que los mensajes incluyan el término limpias. Dicho término, desde un punto de vista semántico, hace referencia a las energías no contaminantes; pero, desde una perspectiva imaginaria, destaca el valor del agua limpia purificadora (recordemos que Durand opone el agua limpia estancada en una pila al agua heraclitea y nictomorfa). Así pues, los anuncios incluyen dos símbolos tan arraigados en la conciencia antropológica como el viento y el agua, insistiendo en su valor positivo en cuanto elementos "limpios" o purificadores.

Por lo demás, el anuncio relativo al viento presenta unos hermosos paisajes marinos, pero sin que aparezca ningún molino de energía eólica que pudiera enturbiar su belleza. Así, la energía verde se presenta como una alternativa idílica que solo tiene ventajas y ningún inconveniente. Desde un punto de vista imaginario, se resalta el valor de la tierra madre y del mar, ambos símbolos nocturnos de la inversión unidos a la maternidad, y por ello no resulta fortuito que en el anuncio aparezca una madre, ya que es un símbolo que se une a la misma constelación. 
De esta forma, se potencian todos los valores de la naturaleza maternal unidos a la simbología nocturna de la inversión.

$\mathrm{Y}$ en cuanto a la niña que hincha una bolsa al viento (imagen 1), constituye en el anuncio el sustituto del molino, lo cual tiene una clara justificación desde un punto de vista imaginario.

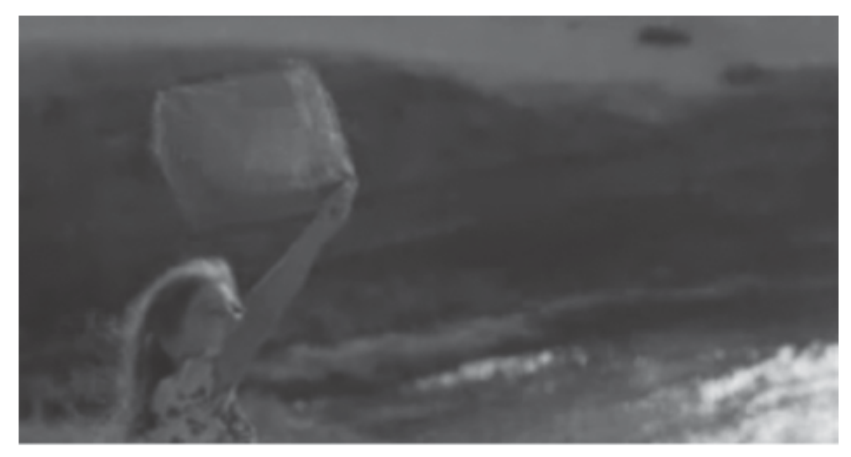

Imagen 1. Niña llenando una bolsa de viento

Los molinos de energía eólica se caracterizan por su enorme tamaño, lo que, en principio, podría ser valorado de distintas maneras: ya hemos visto que la gigantización es un símbolo positivo, ascensional, incluido en el apartado de "El cetro y la espada" del Régimen Diurno; pero el enorme tamaño también puede ligarse a la simbología teriomorfa de "Los rostros del tiempo", la parte negativa del Régimen Diurno, ya que los ogros o gigantes que persiguen a los niños en los cuentos infantiles, o los malvados contra los que luchan los héroes diminutos, suelen tener un gran tamaño que acrecienta su maldad. $\mathrm{Y}$ en el caso de los molinos, es precisamente su gran tamaño lo que les convierte en una amenaza para el paisaje. Por ello, quienes repudian la proliferación indiscriminada de molinos de energía eólica en paisajes emblemáticos, los perciben de forma inconsciente como enemigos o monstruos teriomorfos que devoran el paisaje, es decir, con un valor parecido al que otorgaba a los manchegos molinos de viento la imaginación de don Quijote, que los convertía en malvados gigantes contra los que un héroe diairético como él debía arremeter. La sensación que se experimenta al pasar bajo los molinos, por otra parte, es de temor ante una posible caída y un aplastamiento catamorfo, agravada por el miedo a las aspas que podrían decapitarnos (común al que experimentan algunas personas ante los simples ventiladores de techo). Pero los molinos tienen un claro componente que los une a la simbología cíclica de los utensilios del progreso (es decir, de todos aquellos instrumentos de carácter cíclico - como el torno del alfarero, o los antiguos molinos de 
moler-ideados para colaborar al progreso tecnológico de la humanidad), pues el movimiento circular de sus aspas es un claro símbolo del ciclo. Pues bien, para contrarrestar la imagen inconsciente del enorme molino como un enemigo aplastante o devorador se presenta la figura de la niña con su bolsa, que ejerce en el anuncio como sustituta del molino. Y ello puede ser así porque la bolsa que alza la niña se hincha al viento de igual forma que este mueve las aspas situadas en lo más alto del molino, lo que permite establecer la figura retórica de la metáfora y la subsiguiente sustitución de una imagen por otra. Por lo demás, la bolsa que la niña llena de viento podría constituir un juego de palabras con la salida a bolsa de Iberdrola que se comunica al final del anuncio. Pero, desde un punto de vista imaginario, la sustitución es adecuada porque el hijo (en este caso la hija) también es un símbolo cíclico, encuadrable en la dominante sexual (Régimen Copulativo) de la clasificación de Durand. Si el molino tiene una simbología en parte teriomorfa y en parte cíclica, puede ser ventajosamente sustituido por otro símbolo cíclico (la niña), que supone además una inversión nocturna de su gran tamaño, ya que el enorme molino es gulliverizado en una inofensiva niña.

En el anuncio dirigido a los clientes ${ }^{8}$, aparecen una serie de imágenes alusivas a la energía eólica: una mujer está sentada en el sofá de su casa, y ante ella pasa volando un ave rapaz; otra mujer utiliza en su casa un secador de pelo, y, al ampliarse el enfoque, la estancia aparece llena de vegetación; una niña duerme en su cama y una ardillas saltan sobre ella; aparece después un paisaje con un lago, y una cara de una mujer en primer plano con un molino solitario de fondo; otra imagen insiste en mostrar un solo molino en un paisaje natural; se muestra a continuación una cascada con unos jóvenes sentados en unas piedras y, después, otra serie de jóvenes sobre un paisaje con un río. Y al tiempo una voz en off emite el siguiente mensaje: "Hoy, miles de personas ya se han cambiado a la energía verde Iberdrola. Ya cuidan del medio ambiente. Y tú, ¿̇a qué esperas? Cuantos más seamos más cuidaremos de nuestro planeta. Cámbiate a la energía verde Iberdrola. 901202020”.

En este anuncio, para animar a los destinatarios, se recurre al argumento retóricopersuasivo de la influencia de la mayoría (o "argumento de la mayoría"), basado en el supuesto de que una gran cantidad de personas no puede estar equivocada (Perelman y Olbrechts-Tyteca 2000: 148, 473; Pujante 2003: 147); es decir, se recurre a la fiabilidad que aportan esas "miles de personas" que ya se han cambiado a Iberdrola (se da por supuesto que los destinatarios son clientes de alguna empresa eléctrica, por lo que

8. En $<$ http://www.youtube.com/watch?v=qg-57vPAG_A $>$ (Acceso 9 Agosto 2012). 
en este caso no se trata de incitarles a contratar algo nuevo, sino a que se pasen a la compañía). Y casi se reprocha al destinatario por medio de la interrogación retórica ("Y tú, ¿a qué esperas?") el hecho de que aún no se haya decidido a cuidar del planeta, es decir, a ser cliente de Iberdrola, como si ambas cosas estuvieran inseparablemente unidas. E1 uso del tuteo, y la presencia en el anuncio de personas jóvenes, indica claramente el tipo de cliente que la empresa espera captar. Y en el sintagma "energía verde Iberdrola", que se repite dos veces en un corto mensaje, se elide la preposición de ("energía verde [de] Iberdrola") para identificar en mayor media los términos que lo componen (energía verde=Iberdrola), identificación artificial que, no obstante, se sustenta en el hecho de que ambas partes presenten los mismos sonidos (verde / Iberdrola) ${ }^{9}$, cuya reiteración consigue además sugestivos efectos sonoros. Pero me interesa destacar, en este caso, el modo de tergiversar la realidad de los parques eólicos por medio de las imágenes del anuncio, ya que aparece en dos ocasiones la imagen de un único molino: la primera, tras la cara de una joven mujer, cuya figura en primer plano minimiza el molino que se ve detrás ( $\mathrm{y}$, como es bien sabido, la imagen de una hermosa mujer es empleada frecuentemente en la publicidad para asociarla al producto que se trate de promocionar); la segunda, situado en la esquina de un amplio paisaje, lo que colabora más aún a difuminar su presencia, como se observa en la imagen 2.

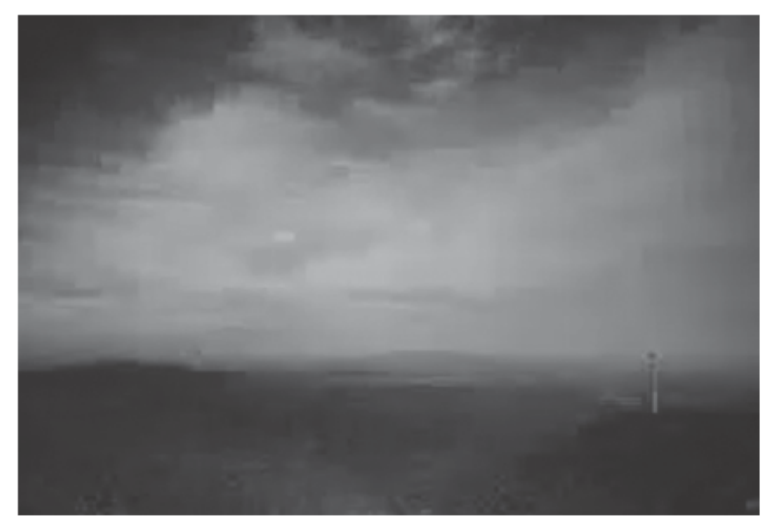

Imagen 2. Molino solitario y paisaje

9. Como explicaba Jurij M. Lotman (1970: 152-173), una de la causas que determinan la compleja estructura de los textos líricos es que la semejanza sonora entre dos palabras (debida a la rima al final de los versos, o a las rimas o reiteraciones fonéticas en el interior de los mismos) puede originar una relación de semejanza semántica entre ellas que no se produce en la comunicación habitual, principio que se puede extender al lenguaje retórico de los anuncios publicitarios, el cual presenta recursos en parte similares a los de los textos líricos. 
Así, los parques eólicos, formados generalmente por un gran número de molinos que se extienden en el espacio deteriorando el paisaje, quedan reducidos a un simple molino que apenas parece distorsionar el valor paisajístico del lugar en que se enclava. Desde un punto de vista imaginario, se trata de un claro proceso eufemístico de gulliverización (símbolo nocturno de la inversión), por medio del cual los enormes molinos teriomorfos se convierten en un diminuto y único molino que aparece integrado en el paisaje sin causar disonancias.

En otros anuncios posteriores, se ensayaron procesos similares de tergiversación, destinados a eufemizar la parte negativa de los molinos de energía eólica o a presentar una visión exclusivamente positiva de los mismos. Me referiré tan solo a tres imágenes que me resultan especialmente significativas. En un anuncio de $2009^{10}$, aparece una imagen de una gran cantidad de gente en movimiento por el campo, que se dirige decidida a un determinado lugar. Vemos después que todas esas personas están formando un muro con sus propios cuerpos, subiéndose unas sobre los hombros de otras, y que ese muro constituye una presa hidráulica que cierra un pantano. De sus aguas surgen nadadores que, atravesando el océano, llegan en multitud hasta la Estatua de la Libertad en la ciudad de Nueva York. A partir de este momento, la música de fondo se sustituye por una voz en off, que se sobrepone a otra imagen en la que aparecen, en el centro y a la derecha, unos molinos (tres destacados en primer plano y otros de fondo), y, a la izquierda, otra curiosa imagen de un molino en formación, constituido por una gran cantidad de personas vestidas de blanco que se van subiendo, nuevamente, unas sobre otras, y que sostienen finalmente las aspas del molino sobre sus cabezas, mientras el viento mueve sus ropas. Y junto a un molino "humano" ya formado, se va construyendo otro similar. Aparece después una imagen de un campo verde con varios molinos, y otra imagen final de un monte sobre una capa de nubes con dos molinos a su izquierda (uno de los cuales apenas se ve un instante) y otro semioculto tras la cima del monte y el resplandor del sol poniente. Y mientras se ven estas imágenes, la voz en off afirma lo siguiente: "Un objetivo, una visión y un equipo para hacerlos realidad. Iberdrola: una manera de hacer las cosas".

Es de resaltar que este mensaje lingüístico, por sí solo, no resultaría demasiado esclarecedor, pues no se explica cuál es el objetivo, ni la visión, ni el equipo que se mencionan. Asimismo, el lema "Iberdrola. Una manera de hacer las cosas" resultaría en sí mismo insuficiente, o, cuando menos, ambiguo, pues no se explica lingüísticamente en qué consiste esa manera de actuar (aunque su situación contextual en un

10. En $<$ http://www.youtube.com/watch? $\mathrm{v}=$ dy6i-Smc4TA\&feature=related $>$ (Acceso 8 Agosto 2012). 
anuncio publicitario le otorgue un valor supuestamente positivo, ya que es sabido que los anunciantes tienden a hablar bien de sí mismos). Las imágenes, en cambio, proporcionan por sí solas una mayor cantidad de información, pues dan a entender que Iberdrola ha implicado a una gran número de personas en su empresa, que estas colaboran entusiastamente en sus objetivos y que se ha expandido hasta el centro económico del mundo (simbolizado por la imagen de la ciudad de Nueva York). La visión de personas subiéndose unas encima de otras con una clara finalidad común, la de construir presas o molinos (atractiva imagen que se materializa por medio de "efectos especiales"), sugiere las ideas de objetivo, visión y equipo tanto o más que los propios términos lingüísticos, si bien el mensaje del anuncio resulta de la conjunción entre el lema y las imágenes, de manera que el primero se sustenta en las segundas.

Pero conviene resaltar, desde un punto de vista imaginario, la eficacia de la imagen del molino de viento formado por personas (imágenes 3 y 4).
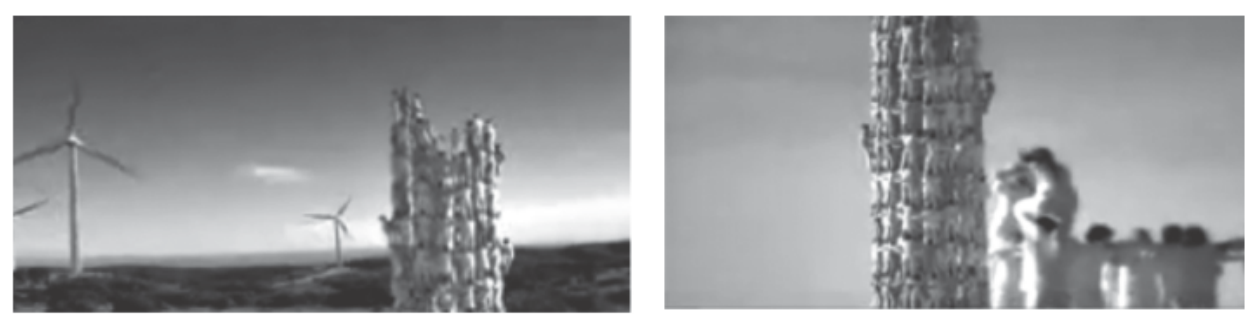

Imágenes 3 y 4. Molinos de energía eólica formados por personas

Desde un punto de vista retórico, la imagen de los hombres vestidos de blanco que forman un molino constituye una imagen metafórica de gran originalidad, que recuerda los castellets del folclore catalán (en los que tal vez se inspira). Así, se hace ver que los molinos son comparables a esos castillos humanos, lo que sugiere que tienen en sí mismos un componente humano nacido de la cooperación, un componente que los humaniza. Además, el gran número de personas implicadas en la construcción del molino insiste en la idea de que un grupo tan numeroso de personas no puede estar equivocado ("argumento de la mayoría"). Y, por lo que respecta a la perspectiva imaginaria, si antes veíamos que los molinos podían sugerir una simbología teriomorfa-catamorfa derivada de su gran tamaño y agresividad y de la posibilidad de su caída con el consiguiente aplastamiento, la imagen del molino formado por personas que se suben unas sobre otras contrarresta eficazmente esa visión. Dicha imagen, que presenta en el anuncio la misma simbología que los castellets, muestra a un grupo humano enfrentándose de forma ascensional a la caída catamorfa y creciendo de forma valerosa (diairética) para vencerla. La sim- 
bología diurna de la elevación se ve acompañada por las imágenes del viento en las ropas de las personas que sostienen las aspas del molino, lo que se relaciona con el símbolo diurno del aire ascensional y diairético. E incluso los ropajes blancos de las personas (necesarios para configurar el color blanco del molino) sugieren la luminosidad propia de los símbolos espectaculares y la pureza de la simbología diairética. Así, frente al peligro de los símbolos teriomorfo-catamorfos, que se incluyen en la parte negativa del Régimen Diurno (la formada por los símbolos de "Los rostros del tiempo"), se alza la triple simbología ascensional-espectacular-diairética de la parte positiva del mismo régimen ("El cetro y la espada"). Y como la imagen resulta en sí mismo sugestiva, pues es el resultado de comparar de manera original un molino de viento con una suerte de castillo humano, aúna la singularidad de su atractivo con la universalidad de su significado simbólico, lo que puede explicar su eficacia comunicativa. No es extraño que en este anuncio, a diferencia del que comentábamos anteriormente, se dejen ver más molinos (aunque nunca de forma masiva), pues previamente se ha sugerido el carácter diurno positivo y altamente humanizado de los mismos, si bien la imagen final tiende nuevamente a escamotear su presencia desmedida, presentando apenas un molino visible que acaba siendo sustituido por el paisaje.

Otra imagen interesante aparece en el anuncio de 2010 que, bajo el lema "Iberdrola. Queremos ser tu energía" (muy similar al "Queremos ser tu banco" empleado en su publicidad por el Banco de Santander), propone una serie de metáforas y comparaciones visuales que comparan las luces de una ciudad con una serie de lamparillas que se encienden en el campo, los géiseres con el vapor que sale de unas planchas de ropa..., y los parques eólicos con una fila de ventiladores caseros ${ }^{11}$, como se ve en la imagen 5 .

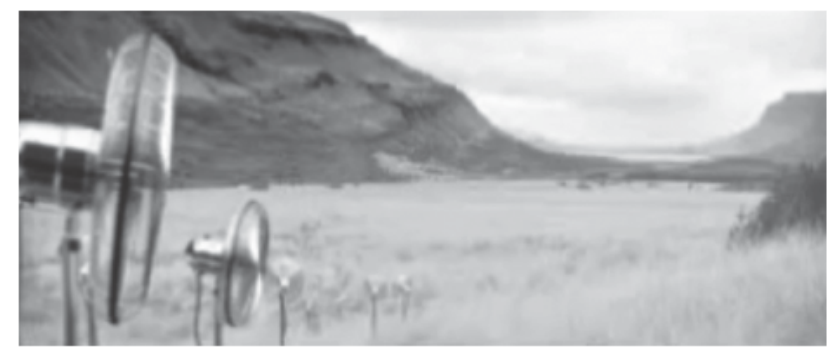

Imagen 5. Ventiladores en lugar de molinos

11. En $<\mathrm{http}: / /$ www.youtube.com/watch?v=zB3lie3Ahvg o http://www.youtube.com/watch? $\mathrm{v}=\mathrm{L} 56 \mathrm{~V} 2 \mathrm{sdtOTg}>$ (Acceso 9 Agosto 2012). 
De esta forma, se recurre a las figuras retóricas de la metáfora y de la comparación para sugerir de forma llamativa la relación entre los elementos de la naturaleza y los utensilios eléctricos que usamos en el hogar, cuya energía es proveída por la empresa anunciante. Pero si los géiseres (que se comparan con planchas) son elementos naturales, no ocurre lo mismo con las luces de las ciudades o con los molinos de viento. A este respecto, es de notar que hay en el anuncio una mezcla intencionada de metáforas y comparaciones: las lámparas que se encienden sugieren metafóricamente las luces de una villa, pero esta no aparece; los ventiladores eléctricos situados en el campo apuntan metafóricamente a los parques eólicos, pero estos no se muestran, mientras que sí aparecen imágenes de géiseres que se comparan expresamente (y ya no de forma metafórica, pues ahora sí figuran los dos términos de la comparación) con el vapor que emiten las planchas (si solo se mostrara el vapor de las planchas, difícilmente se sugeriría la idea de un géiser). Se pretende insinuar así la identidad entre todos los elementos que aparecen, disminuyendo el carácter artificial de la iluminación nocturna de las ciudades o de los parques eólicos, ya que se asocian con elementos naturales como los géiseres. Desde un punto de vista imaginario, cabe resaltar que los enormes molinos de energía eólica son sustituidos por pequeños ventiladores, con lo que la simbología teriomorfa de los mismos es claramente eufemizada merced a los símbolos nocturnos de la inversión, que eliminan la negatividad de los molinos transmutándolos en aparatos domésticos (simbología de la intimidad) y gulliverizados.

En otro de los anuncios de la empresa, de $2010^{12}$, se trata también de eufemizar el enorme tamaño de los molinos y las molestias que pudieran producir, pero de manera diferente. En él aparece el primer plano de un hombre que ha de agachar la cabeza para esquivar algo sonoro que pasa ante él, y que va diciendo lo siguiente: "Para ahorrar con Iberdrola el 30\% del fijo del gas, y el 10\% del de la luz, ¿tengo que tener un molino en mi casa?". La imagen entonces se amplía, y vemos que el hombre está en el piso alto de su vivienda, de tipo dúplex, y que en el piso bajo aparece instalado un molino de energía eólica, cuyas aspas giratorias eran lo que el hombre esquivaba, como se observa en la imagen 6.

12. En $<$ http://www.youtube.com/watch? $\mathrm{v}=\mathrm{SptXmiolY} 68>$ (Acceso 9 Agosto 2012). 


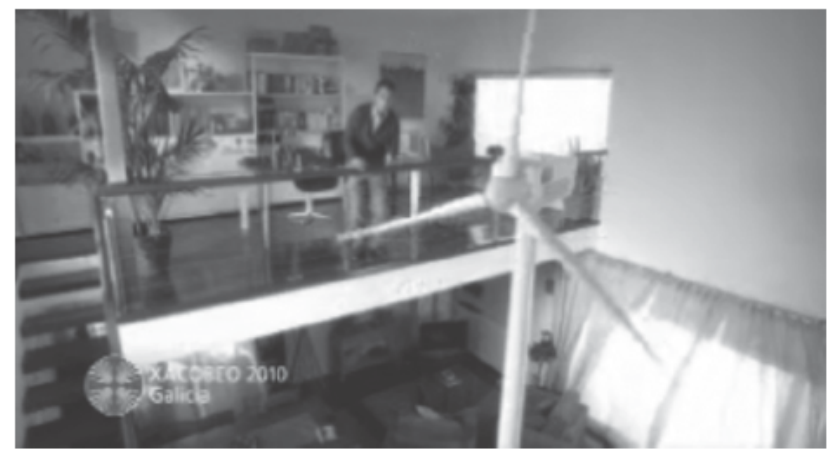

Imagen 6. Molino en casa

La respuesta a la pregunta la da una voz en off: "No. Es tan sencillo como llamar al 900225235 y contratar luz y gas Iberdrola". Y vemos después al hombre, muy satisfecho, realizando la llamada telefónica sugerida. El anuncio va dirigido a conseguir que los destinatarios contraten con Iberdrola los servicios de gas y luz, pero tiene un componente añadido destinado a minimizar el daño que puedan causar los molinos al paisaje. En rigor, no habría sido necesario incluir la imagen de un molino en el hogar para propiciar que los clientes contrataran los servicios mencionados de Iberdrola, pero el anuncio se aprovecha para contrarrestar la principal pega que puede ponérsele a los molinos. Si en el anuncio comentado anteriormente los molinos se gulliverizaban en simples ventiladores domésticos, ahora se insiste en que no hay que tener un molino dentro de casa para gozar de las ventajas que proporciona Iberdrola a nuestro hogar. Desde un punto de vista retórico, la idea del anuncio puede resultar chocante y atractiva por su falta de verosimilitud, lograda mediante el uso de la figura de la hipérbole (la idea de tener que meter un enorme molino en casa). Hay también una comparación encubierta, pues se sugiere que hay dos lugares posibles donde instalar los molinos, en casa y en el campo (aunque el primero de ellos sea absurdo), invitándonos a elegir el mejor. Y, por medio del procedimiento retórico del silogismo encubierto se transmite el siguiente mensaje subliminal: los molinos en casa molestan; los molinos no están en casa, luego los molinos no molestan. $\mathrm{O}$, dicho de otra manera, si tuviéramos que instalar los molinos en nuestra propia casa, tendríamos motivos para inquietarnos, pero no debemos preocuparnos, ya que los molinos, instalados donde les corresponde, no nos causan ninguna molestia. Así, la imagen hiperbólica se usa para sugerir que el lugar de emplazamiento "natural" de los molinos es el campo, y que, si están en su sitio, son inofensivos y no nos afectan directamente (mensaje que podría calar en aquellas personas despreocupadas por el paisaje y la naturaleza); o, cuando menos, se da a entender, por medio del argumento retórico-persuasivo del "mal menor", 
que el lugar donde menos daño hacen los molinos es en el campo, aunque sea inventando un término absurdo para realizar la comparación, pues a nadie -salvo al publicista- se le ocurriría que los molinos tuvieran que estar en los hogares (donde no suele haber el fuerte viento que sopla, al parecer, en la casa del anuncio, capaz de mover las aspas del molino). Pero, desde un punto de vista imaginario, la idea del molino en casa adquiere una significación añadida, pues tanto la tierra (en la que se instalan los molinos) como la casa pertenecen a la misma dominante digestiva del Régimen Nocturno: la tierra, o madre-tierra, asociada a la maternidad, es un símbolo de la inversión, y la casa, ligada también al hogar primigenio y a la protección maternal, es un símbolo de la intimidad. Quiere esto decir que, desde un punto de vista imaginario, la tierra y la casa se identifican, por lo que la idea de trasladar los molinos de la tierra a la casa tiene un fundamento antropológico que refuerza el sentido de la imagen y favorece su efectividad. Además, la tierra y la casa son intercambiables, con lo que el anuncio sugiere que, si los molinos no afectan a nuestro ámbito más íntimo y privado, la casa, tampoco tienen por qué dañar a la madre-tierra. Por otra parte, y aunque el molino aparezca en el anuncio como un elemento perturbador, está parcialmente eufemizado o gulliverizado, pues su tamaño es sensiblemente menor al que tienen los molinos reales, que no podrían instalarse de ninguna manera en el interior de una vivienda, ni aunque fuera un dúplex. Y el hecho de que en varios anuncios se trate de eufemizar o minimizar el daño que los molinos pueden causar al paisaje muestra la preocupación al respecto de los emisores del anuncio, aunque nunca se refieran a ello expresamente.

Por lo demás, Iberdrola se convirtió en patrocinadora oficial de la Selección Española de Fútbol, por lo que algunos de sus anuncios incluyeron imágenes de sus jugadores, tratando de aprovechar el éxito deportivo esperable (y que finalmente obtuvo) en el Campeonato Mundial de Sudáfrica de 2010 y en la Eurocopa de 2012. En un anuncio de $2010^{13}$, se simultaneaban las imágenes de algunos jugadores de la Selección en el campo de fútbol con las del viento soplando en el campo y las de molinos de energía eólica (siempre en pequeña cantidad, y algunos de ellos semiocultos), al tiempo que las voces de los distintos jugadores emitían el siguiente mensaje: "Yo quiero ser como el viento. Siempre por delante. Yo quiero ser como el viento: fuerte, rápido, inagotable. Eso quiero ser". Y otra voz en off cerraba el anuncio con el siguiente lema: "Iberdrola: impulsor oficial de la Selección Espa-

13. En <http://www.prnoticias.com/index.php/marketing/sala-de-prensa-de-marketing/1098campanas/20114447-iberdrola-lanza-una-campana-con-la-seleccion-espanola-de-futbol> (Acceso 9 Agosto 2012). 
ñola de Fútbol" (donde el término "impulsor", en lugar del habitual "patrocinador", remite a la idea del viento impulsando las aspas de los molinos). Y en un anuncio de $2012^{14}$, se recurría nuevamente a la visión de una gran cantidad de personas ("argumento de la mayoría") corriendo por el campo, esta vez en una larga fila, que finalmente aparecía encabezada por varios jugadores de la Selección, los cuales volaban por los aires para chutar el balón, de manera que la larga fila de personas (continuando la imagen del molino formado por personas que se subían unas sobre otras del anuncio que hemos visto anteriormente), representaría metafóricamente el cuerpo del molino, mientras que los jugadores de la selección equivaldrían a sus aspas. Y para reforzar la asociación, aparecían al fondo unos molinos (imagen 7).

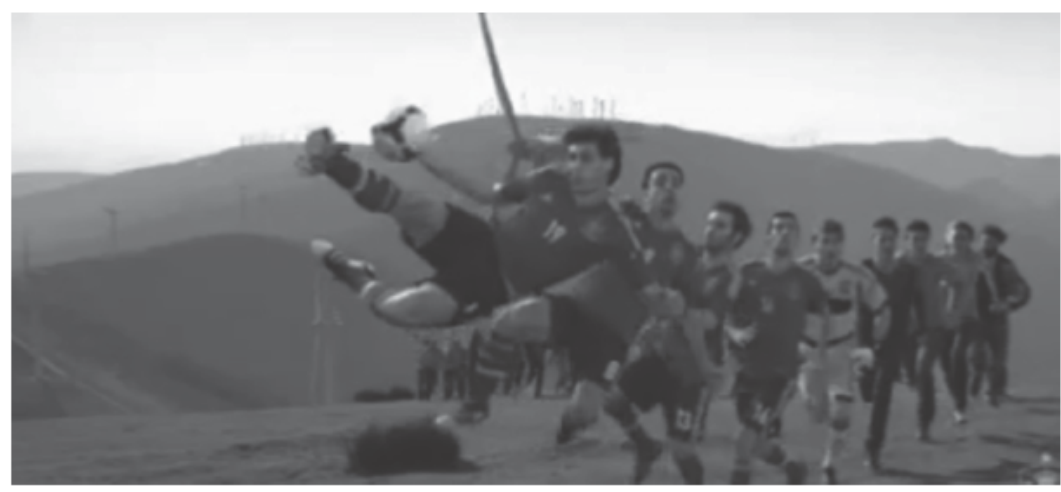

Imagen 7. La Selección Española de Fútbol y los molinos de energía eólica

Desde un punto de vista retórico, la simple asociación comparativa entre el viento que mueve los molinos de Iberdrola y los jugadores de la selección, muy valorados tras sus triunfos, puede resultar eficaz. Además, se recurre encubiertamente a la idea tradicional que destacaba la furia de la Selección Española, concepto que se asocia eficazmente a la energía que producen los molinos, sugiriendo que la energía de Iberdrola sustenta la furia de la Selección. Y, desde un punto de vista imaginario, se valora nuevamente el carácter ascensional y diairético del viento, que se asimila al carácter también diairético de los jugadores de fútbol. A este respecto, no hay que olvidar que la generalidad de los deportes, y el fútbol en particular (cuyo éxito y singularidad seguramente deviene de la prohibición -excepto en el caso del portero- de tocar el balón con las manos, lo que elimina el uso de uno de los ele-

14. En 〈http://www.youtube.com/watch?NR=1\&v=tA3QjSsTlkA\&feature=endscreen $>\mathrm{o}$ $<$ http://www.youtube.com/watch?v=pnY0Jtb9d0I $>$ (Acceso 9 Agosto 2012). 
mentos que más nos distinguen de los animales, y en parte por ello animaliza a los jugadores, pero los obliga también a desarrollar una suerte de habilidad complementaria con los pies), constituyen una simulación eufemizada de la guerra, por medio de la cual, como actores o espectadores, podemos encauzar nuestras tendencias belicosas sin producir graves daños (aunque, en ocasiones, el carácter violento subyacente al deporte resurja en los enfrentamientos entre las distintas aficiones y en los destrozos que causan los hinchas que "invaden" países o lugares ajenos). Así, los dos equipos enfrentados en el campo (de batalla) visten, como los ejércitos, su propio uniforme y lucen su propia bandera, y la terminología deportiva se sirve recurrentemente de términos belicosos (ataque, defensa, victoria, derrota, rival, disparo, cañonero...). Algunos deportistas van eufemísticamente armados (raquetas, bates...), y, en ocasiones pueden producir lesiones con sus "armas" (sticks, tacos de las botas de fútbol o de rugby...). Los partidos en el propio campo o las visitas al campo rival simulan las defensas o invasiones del territorio propio o ajeno, y los triunfos o las derrotas se celebran o lamentan en ocasiones como si la ciudad o la nación entera hubieran ganado o perdido una batalla (si bien cabe el consuelo de ganar la próxima vez, pues los deportes también instauran un calendario cíclico que permite la muerte simbólica y la resurrección propias del Régimen Copulativo). La simbología antropológica del deporte, en suma, está profundamente arraigada en el imaginario colectivo, lo que explica su éxito entre las masas y el que pueda ser usado fácilmente por los dirigentes políticos con fines manipuladores. Pues bien, siendo los deportistas los héroes épicos de la actualidad, mantienen una simbología guerrero-diairética que les hace fácilmente asimilables a la simbología también diairética y ascensional de los molinos de energía eólica. Además, los jugadores refuerzan su simbología ascensional al manifestar, en el primer anuncio, que quieren ser como el viento, y al aparecer, en el segundo, casi volando al chutar el balón. En los anuncios que equiparan el viento y la energía que producen los molinos con la energía que muestran los jugadores de la selección no se pretende, por lo tanto, eufemizar o minimizar el aspecto negativo de los molinos, sino que se apuesta por valorar positivamente su capacidad ascensional y diairética para producir energía, tratando de asociar su imagen a la también ascensional y diairética de los jugadores de la Selección Española de fútbol, muy valorados por gran parte de la población tras sus recientes éxitos deportivos, en un intento de presentar una visión exclusivamente positiva de los molinos que oculte sus inconvenientes.

En suma, los anuncios comentados de Iberdrola tratan de mostrar los efectos más positivos de la energía eólica (la generación no contaminante de electricidad y la consecuente producción de beneficios económicos) y de minimizar su aspecto más negativo (el daño paisajístico que produce la implantación desmesurada y ar- 
bitraria de los parques eólicos). Para ello, se sirven de distintos recursos retóricos, como los argumentos basados en la influencia de las mayorías o en el "mal menor", los silogismos encubiertos o las figuras retóricas (metáfora, hipérbole y comparación). Pero, además, despliegan procedimientos simbólico-imaginarios que tratan, por una parte, de eufemizar la simbología teriomorfa de los molinos de energía eólica por medio de su gulliverización, y, por otra, de ensalzar los aspectos positivos derivados de su simbología ascensional-diairética. El análisis realizado indica que la tergiversación persuasiva no solo atañe a los recursos retóricos, sino también a la manipulación y presentación de los símbolos, y muestra que la metodología analítica suministrada por la Poética del imaginario puede constituir un complemento satisfactorio para analizar y poner al descubierto las estrategias persuasivas de los anuncios publicitarios.

\section{Bibliografía}

ALBALADEJO MAYORDOMO, T. (1989). Retórica. Madrid: Síntesis.

ALBALADEJO MAYORDOMO, T. (1999). "Los géneros retóricos: clases de discurso y constituyentes textuales" en Téchne Rhetoriké. Reflexiones actuales sobre la tradición retórica. (Coord. Isabel Paraíso). Valladolid: Universidad de Valladolid: 55-64.

ARISTÓTELES (1985). Retórica. (Ed. bilingüe de Antonio Tovar). Madrid: Centro de Estudios Constitucionales.

BACHELARD, G. 1978 (1942). El agua y los sueños. Ensayo sobre la imaginación de la materia. México: Fondo de Cultura Económica.

BACHELARD, G. (1948a). La terre et les rêveries du repos. Essai sur les images de l'intimité. París: J. Corti.

BACHELARD, G. (1948b). La terre et les rêveries de la volonté. Essai sur l'imagination des forces. París: Corti.

BACHELARD, G. (1957). Poética del espacio. México: Fondo de Cultura Económica.

BACHELARD, G. (1958). El aire y los sueños. Ensayos sobre la imaginación del movimiento. México: Fondo de Cultura Económica.

BACHELARD, G. (1961). La flamme d'une chandelle. París: Corti.

BACHELARD, G. (1966). Psicoanálisis del fuego. Madrid: Alianza Editorial.

BLOMMAERT, J. (2005). Discurse. Cambridge: Cambridge University Press.

BURGOS, J. (1982). Pour une poétique de l'imaginaire. París: Seuil.

DIJK, T. A. VAN (1980). Texto y contexto. Semántica y Pragmática del discurso. Madrid: Cátedra. 
DIJK, T. A. VAN (1999). Ideología. Un enfoque multidisciplinario. Barcelona: Gedisa.

DIJK, T. A. VAN (2001). "Multidisciplinary CDA: a plea for diversity" en Methods of critical discourse analysis. (Coords. R. Wodak y M. Meyer). Londres: Sage: 95-120.

DIJK, T. A. VAN (2003). Ideología y discurso. Barcelona: Ariel Lingüística.

DIJK, T. A. VAN (ed.) (1997). Discourse as structure and process. London: Sage.

DURAND, G. 2005 (1960). Las estructuras antropológicas del imaginario. Madrid: Fondo de Cultura Económica.

DURAND, G. (1961). Le décor mythique de la Chartreuse de Parme. Contribution a l'esthétique du romanesque. París: J. Corti.

DURAND, G. 1993 (1979). De la mitocritica al mitoanálisis. Barcelona: Anthropos.

DURAND, G. 2000 (1994). Lo imaginario. Barcelona: Ediciones del Bronce.

DURAND, G. (1996). Introduction à la mythodologie. París: Albin Michel.

FAIRCLOUGH, N. (2001). "Critical discourse analysis as a method in social scientific research" en Methods of critical discourse analysis. (Coords. R. Wodak y M. Meyer). Londres: Sage: 122-138.

GARCÍA BERRIO, A. (1985). La construcción imaginaria en "Cántico" de Jorge Guillén. Limoges: Université de Limoges.

GARCÍA BERRIO, A. (1994). Teoría de la Literatura. Madrid: Cátedra.

GENETTE, G. (2000). La obra del arte II: La relación estética. Barcelona: Lumen.

GOFFMAN, E. (2006). Frame Analysis. Los marcos de la experiencia. Madrid: Centro de Investigaciones Sociológicas.

HERNÁNDEZ GUERRERO, J. A. y GARCÍA TEJERA, M. C. (2004). El arte de hablar. Manual de Retórica Práctica y de Oratoria Moderna. Barcelona: Ariel.

IACOBONI, M. (2010). Las neuronas espejo. Empatía, neuropolítica, autismo, imitación o de cómo entendemos a los otros. Madrid: Katz Editores.

JEANNEROD, M. (2002). Le cerveau intime. París: Odile Jacob; Cité des sciences et de l' industrie.

KIBEDI VARGA, Á. (2000). "Universalité et limites de la rhétorique". Rhetorica 18 (1): $1-28$.

LAKOFF, G. (2007). No pienses en un elefante. Lenguaje y debate politico. Madrid: Universidad Complutense de Madrid.

LAUSBERG, H. (1990). Manual de Retórica literaria. Fundamentos de una ciencia de la literatura (3 vols.). Madrid: Gredos.

LAUSBERG, H. (1993). Elementos de retórica literaria. Madrid: Gredos.

LEDOUX, J. (1999). El cerebro emocional. Barcelona: Ariel-Planeta.

LOTMAN, J. M. 1988 (1970). Estructura del texto artístico. Madrid: Istmo. 
MARTÍN JIMÉNEZ, A. (1993). Tiempo e imaginación en el texto narrativo. Valladolid: Universidad de Valladolid.

MORALES LÓPEZ, E. (2004). "Las aproximaciones americanas al análisis del discurso oral: perspectivas de futuro" en Caminos de la semiótica en la última década del siglo XX. (Coord. D. Pujante Sánchez). Valladolid: Universidad de Valladolid: 109-123.

MORTARA GARAVELLI, B. (1991). Manual de Retórica. Madrid: Cátedra. PERELMAN, Ch. (1988). La lógica jurídica y la nueva retórica. Madrid: Civitas. PERELMAN, Ch. (1989). Rhétoriques. Bruselas: Éditions de l'Université de Bruxelles.

PERELMAN, C. y OLBRECHTS-TYTECA, L. (1994). Tratado de la argumentación: la nueva retórica. Madrid: Gredos.

PROPP, V. (1998). Las raíces históricas del cuento. Madrid: Fundamentos.

PUJANTE SÁNCHEZ, D. (2003). Manual de Retórica. Madrid: Castalia.

PUJANTE SÁNCHEZ, D. (2010). "Lo alemán como garantía de calidad para el mercado automovilístico español: el lanzamiento del Citroën C5 (La teoría de Perelman sobre la argumentación y la tópica de la esencia)". Tonos Digital 19 $<$ http://www.um.es/tonosdigital/znum19/secciones/estudios-20-C5.htm>.

PUJANTE SÁNCHEZ, D. y MORALES LÓPEZ, E. (1996-97). "Discurso político en la actual democracia española". Discurso 21-22: 39-75.

PUJANTE SÁNCHEZ, D. y MORALES LÓPEZ, E. (2003). "Intervención del líder de la oposición Josep Borrell en el debate sobre el estado de la nación española de 1998: análisis de un discurso fracasado". Monteagudo 8: 107-160.

PUJANTE SÁNCHEZ, D. y MORALES LÓPEZ, E. (2008). "A political action against popular opinion". Journal of Language and Politics 7 (1): 71-96.

RIZZOLATTI, G. y SINIGAGLIA, C. (2006). Las neuronas espejo. Los mecanismos de la empatía emocional. Barcelona: Paidós.

RUBIO MARTÍN, M. (1991). Estructuras imaginarias en la poesía. Gijón: Júcar.

SALAZAR QUINTANA, L. C. (2009). La Poética de la imaginación en el texto narrativo: elementos para la interpretación simbólica de la Primera parte del "Quijote" de Miguel de Cervantes. Tesis Doctoral inédita. Dpto. de Literatura Española y Teoría de la Literatura y Literatura Comparada de la Universidad de Valladolid.

WODAK, R. y MEYER, M. (2001). Methods of critical discourse analysis. Londres: Sage.

ZEA ÁLVAREZ, F. (2003). La subversión de los símbolos en la Poética de lo imaginario. Trabajo de Investigación de Doctorado inédito. Dpto. de Literatura Española y Teoría de la Literatura y Literatura Comparada de la Universidad de Valladolid. 